\title{
REFORMĀCIJA BIJA UN IR IESTĀŠANĀS PAR BAZNĪCU
}

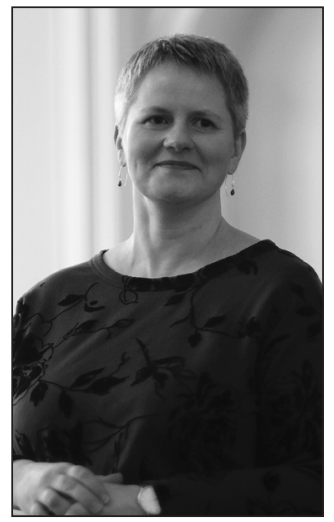

Dace Balode kopš 2000. gada strādā LU Teoloǵijas fakultātē, pašlaik ir šīs fakultātes dekāne un profesore Bībeles teologijiā. Teologiju studējusi LU, kā arī Bāzeles un Bernes Universitātes Teologijas fakultātē, sadarbojoties ar Šveices Jaunās Derības pētnieku profesoru Ulrihu Lucu (Ulrich Luz). Doktora diplomu ieguvusi Tartu Universitātes Teologijijas fakultātē. Akadēmiskās intereses saistās ar biblisko teoloǵiju un tekstu interpretācijas teorijām un vēsturi, kā arī sievietes lomu kristīgajā tradīcijā. Šajās jomās viṇa publicējusi savus pētniecības darbus, tostarp monogrāfiju Gottesdienst in Korinth (Dievkalpojums Korintā, 2011), kas veltīta kristīgā dievkalpojuma pirmsākumiem. Viṇa ir Latvijas Luterāṇu sieviešu teologu apvienības valdes locekle. 2018. gadā ordinēta Latvijas Evanĝ̣ēliski luteriskajā baznīcā ārpus Latvijas.
Raksturvārdi: baznīca, reformācija, reformācija Latvijā, luterisms, ekumene.

Reformācija nav tikai baznīcas vēstures daḷa, šī teologiskā impulsa vadītā norise iespaidoja vispirms Eiropas, bet vēl vairāk visas pasaules vēsturi. Protestantisms, kura pirmsākumi meklējami reformācijas kustībā, pārstāvēts visā pasaulē - sākot no Austrālijas un beidzot ar Ziemel̦ameriku, un ir veidojis gan reliǵiskās, gan politiskās, gan sabiedriskās realitātes un iespaidojis cilvēku mentalitāti. Tas pats attiecināms arī uz Latviju, tādēl reformācijas vēsture ir aktuāla ne tikai reliǵiski ieinteresētiem cilvēkiem, bet visiem, kas apzinās, ka mēs esam tie, par ko mūs vēsture izveido. Tādēḷ šis izdevums veltīts tam, lai meklētu atbildes uz jautājumu, kādu iespaidu luteriskā reformācija un arī tās rezultātā izveidojušās baznīcas atstājušas uz Latviju.

Diskutējot par lingvistisku detalı, vai vārds "baznīca" ir rakstāms ar lielo vai mazo burtu, jāatbild, ka var lietot to abējādi - gan ar lielo, gan mazo. Tas atkarīgs no tā, kas tiek saprasts ar baznīcu. Ja runa ir par lokālo, laikā un telpā ierobežoto cilvēku kopu un arī baznīcas ēku, tad būtu lietojams mazais burts. Taču, ja runa ir par universālo, pārlaicīgo Baznīcu, tad būs teologi, kas izšķirsies lietot lielo burtu B. Ar to tad būtu saprotama universāla Baznīca kā Dieva iestādījums, visu svēto kopība, kas iet cauri visiem laikiem "no mūžības uz mūžību". Š̀ baznīca tad atklājas baznīcā kā šīs pasaules institūcijā, taču nav pilnīgi viens un tas pats. Šāds koncepts palīdz saglabāt tās uzticamību arī tad, ja konkrētā aktuālā baznīca dodas ceḷos, kurus grūti apzīmēt par Dieva celiem.

Lai cik arī doma par pārlaicīgo Baznīcu kā Dieva radītu, gribētu, veidotu cilvēku kopumu ir atbalstāma, jājautā, vai patiešām šāds koncepts par abstraktu Baznīcu nav ideāls, fantoms, sapnis vai utopija. Vai tas beigās nekḷūst par baznīcas konceptu, kurai ar realitāti ir maz sakara. Universālās Baznīcas koncepts, protams, ietver domu par Baznīcu kā vietu, kur sastopama mūžīga, nemainīga patiesība. 
Šo konceptu trāpīgi kritizē atbrīvošanās teolog̣ijā, jo nevar būt patiesība, kas eksistē kaut kur ārpus šīs realitātes kaut kādās patiesības debesīs. ${ }^{1}$ Patiesība var būt patiesība tikai, ja tā īstenojas. Jā, var būt ideāli, mērķi, apziņa, ka kaut kas ir jāmaina, taču, pat ja būtu šì te kaut kur tālajās debesīs esošā îstenība, mums no tā nebūtu nekāda labuma, jo tā nekad nebūtu iespējama. Baznīca tad, tieši otrādi, kā cilvēku kopiena ir tā, kas īstenojas laikā un telpā.

Skaidrs, ka nav ideālas cilvēku kopienas un baznīcas vēsture dažiem šksiet saucama par kriminālvēsturi. ${ }^{2}$ Visbiežāk pie tumšākajām baznīcas vēstures lappusēm tiek piesaukti krusta kari, kas, protams, ir interpretējami noteiktā laikā un uz noteikta norišu fona un tomēr liek jautāt, vai miermīlīgajam sludinātājam Jēzum, kurš l̦āva sevi piesist krustā, ar to vispār ir kāds sakars, kā vienīgi tas, ka viņa vārds tika nelietīgi valkāts, un nav nekā, kas to varētu aizstāvēt. Baznīcas vēsture ne ar ko neatšksiras no visas cilvēces vēstures. ${ }^{3}$ Taču tieši šajā pasaulē ienāk un ir piedzīvojams Dievs un Dieva vārds. Šveices teologs Hanss Veders runā par "svešo viesi", ar to domājot Dieva vārdu, kas ir pilnīgi bezspēcīgs šajā pasaulē, jo ar to var tikt darīts viss, ko vien sirds kāro. Tomēr tieši tāds Dievs izšķiras ienākt šajā pasaulē - bezspēcīgs, lai atvērtu iespēju citādām attiecībām. Starp stiprajiem veidojas konkurence, bet te var sākt veidoties uz citiem principiem balstītas attiecības. Attiecības, kas ved arī pie tā, lai šis Bezspēcīgais tiktu aizstāvēts tajā nevardarbībā, ko tas ietver. ${ }^{4}$ Tas ir atgādinājums korig̣êt

Luz 2014, 270-271.

2 Viens no spilgtākajiem un plašāk izvērstajiem baznīcas kritikas piemēriem ir vācu autora Karlheinca Dešnera darbs desmit sējumos Kristietības kriminālvēsture: Deschner 1986-2014.

3 Baznīcas vēsture teologiski ir dažkārt saprasta kā Dieva pestī̌sanas vēsture, resp., tajā atspogulıojas Dieva pestījošā darbība pie cilvēka šajā pasaulē, tajā Dievs ir atpazīstams. Tā aizsākusies jau laikos, par kuriem vēsta Bībeles teksti, un turpinās tālāk līdz mūsdienām. Iepretī šādam konceptam, piem., vācu teologs Volfārts Pannenbergs saprot visu cilvēces vēsturi kā Dieva atklāsmi, neatdalot tajā kādu īpašu ekskluzīvu vēstures daḷu - vēsturi vēsturē. Tādā veidā visa, arī baznīcas, vēsture ir viens veselums. Sk. Pannenberg 1961.

4 Weder 1986, 434-435. savu eklesiologiju, saprotot, ka pilnīgi noteikti ikvienā baznīcā Dieva vārds tiek nelietīgi valkāts, ar biblisku izteiksmes veidu sakot - sists krustā, un vienīgais, kas, teologiski skatoties, baznīcu var padarīt par baznīcu, t. i., vietu, kur cilvēku kopienā un attiecībās ir Dievs piedzīvojams, ir Dievs. Un šīs Baznīcas robežas reizēm var sakrist ar institucionālās baznīcas robežām, bet reizēm arī ne.

Teologiski skatoties, reformācijā ir saredzams tāds mēǵinājums iestāties par Dieva vārdu, protams, tikpat kḷūdains, cik pareizs, kā daudzi citi mēǵinājumi.

Neapšaubāmi, luteriskā reformācija iez̄̄mē robežšķautni reliǵiskā, politiskā, bet arī valodnieciskā, sadzīiviskā un pat mākslas un mūzikas jomā tā, ka varētu runāt par paradigmu mainu. To neapšaubāmi sagatavo reformas, kas baznīcā jau ir notikušas pirms tam, un daudzi Mārtina Lutera laikabiedri, kas pat iebilda pret dažādām viņa nostādnēm, tomēr saredzēja, ka reformas baznīcā ir ļoti nepieciešamas. Piem., Roterdamas Erasms, viens no tiem, kas teologiski debatēja ar doktoru M. Luteru. Bet ne tikai pirms - arī pēc 1517. gada, kad tika izplatītas M. Lutera 95 tēzes, kas ievadīja dažādus disputus, reformācija turpinājās, un pašlaik tiek runāts par "garo reformāciju", ar to vai nu norādot uz noteiktu laika posmu līdz 17. vai 19. gs., vai apzinoties, ka reformācija kā nemitīgs kritiska izvērtējuma princips baznīcā notiek līdz pat šai dienai.

Šajā izdevumā Valdis Tēraudkalns rakstā Reformācija kā jauna izpratne par baznīcu atgādina, ka reformācija bija daudzveidīgs process un aptvēra ne tikai tos strāvojumus, ko iespaidoja luteriskā teologija, bet arī Kalvina, Cvinglija, Anglijas reformācija, un mūsdienās kā vienu daļu no šñ procesa saprot arī atbildi katoḷu baznīcā uz šìm savā veidā no pašas vidus izrietošajām pārmaiņām, proti, katoḷu reformāciju. Tas, protams, liek jautāt, vai šajā daudzveidībā ir atrodams kaut kas vienojošs, ko saistīt ar vārdu "reformācija", kas tad tiek reformēts, kas ir jaunais šajā visā procesā, kas ir reformācijas atšķirīgais un ippatnais devums kristietības vēsturē. Atbilde saistās ar jaunu izpratni par baznīcas lomu cilvēka attiecībās ar Dievu. Lai arī protestantisms pēc būtības ir daudzveidīgs, lai arī izpratnes par to, kas ir baznīca un kādai tai jābūt, dažādās reformācijas 
baznīcās atškiiras, taču vienojošā ir izmainītā attieksme pret baznīcas hierarhiju - tā protestantismā vairs nav baznīcas patiesības garants un obligāta starpniece starp cilvēku un Dievu. Arī katoḷu baznīcas, pat Romas Katoḷu baznīca, kurā visizteiktāk vēl pastāv hierarhiska baznīcas izpratne, laika gaitā ir iespaidojušās no šīs reformācijas atziņas, kā īpaši redzams pēc Vatikāna II koncila, pēc kura samazinās uzsvars uz hierarhiju kā baznīcu konstituējošo elementu, bet pieaug uzsvars uz draudzi kā savstarpēja atbalsta, misijas, lūgšanu kopību. Citiem vārdiem, reformācija veido cilvēku, kas aicināts spriest un domāt, un vērtēt pats.

Arī Latvijas kontekstā, par kuru vēsta Linarda Rozentāla raksts Luteriskās baznīcas Latvijā pašizpratne - vēsturē un mūsdienās, redzams, ka vienmēr ir pastāvējuši meklējumi pēc formas, kā baznīca var īstenoties. Taču šie meklējumi ir bijuši iespaidoti arī no politiskā konteksta un parāda to, cik l,oti baznīcas un sabiedrības procesi ir savīti. Izsekojot Latvijas Evanggèeliski luteriskajai baznīcai kā institūcijai no tās dibināšanas laika līdz pat mūsdienām, redzams, ka politiskās norises dažādā veidā iespaidojušas baznīcas pašizpratni un strukturālo identitāti. No vienas puses, politiskās norises valstī ietekmēja baznīcu - tā kādā mērā atkārtoja kaut politikā notiekošo, bet arī tieši otrādi - baznīca atrada sevī avotu kritiski nostāties pretī valdošajai politiskajai varai. 20. gs. sākumā luteriskā baznīca Latvijas teritorijā bija cieši saistīta ar valsts varu, tās likumus pieṇēma valsts likumdošanas ceḷā. Pēc Latvijas valsts izveidošanās un Latvijas Evanggéēiski luteriskās baznīcas nodibināšanas 1928. gadā izveidojās baznīcas autonomija. Baznīca šajā laikā patiešām ir tautas baznīca, apvienojot lielāko daḷu Latvijas iedzīvotāju. Ar politiskā autoritārisma izveidošanos Latvijā arī baznīcā vara tiek centralizēta. Tāpat padomju okupācijas laikā baznīca iegūst līdzīgu raksturu kā politiskā vara - tajā it kā darbojas parlaments, taču tam nav reālas varas. Tāpat arī baznīcas pārvalde vairs nav baznīcas "tautas" gribas kalpone, bet ir atkarīga no režīma uzspiestām robežām. Tomēr tieši šajā nebrīvajā stāvoklī baznīcā atrodas potenciāls, kas ir spējīgs veidot pretošanās kustību, opozīciju, kas iestājas pret tai uzspiesto varu un ideoloǵiju, bet nostājas tautas pusē, tādā veidā kḷūstot par tautas baznīcu. Baznīcas tālākpastāvēšana atkal atjaunotajā Latvijā tomēr vēl joprojām ir 20. gs. traumu iezīmēta. Tās arī vairākās paaudzēs iespaido cilvēka garīgos meklējumus. Piedzīvotās traumas, kas rada apdraudētības sajūtu, liek vērtību skalā augstu novietot stabilitāti, skaidrību un skaidras normas. Tas var izskaidrot konservatīivisma un pat fundamentālisma iezīmes pēdējo gadu vēsturē.

Kas tomēr padara baznīcu par baznīcu dažādos laikmetos, vēsturiskos lîkločos? Emeritētā bīskape Jāna Jēruma Grīnberga risina latviešu luteriskās baznīcas identitātes jautājumu rakstā Latvijas evanğgeliski luterisko Baznīcu eklesiologiskā pēctecība. Bieži baznīcas savos nosaukumos ir ietvērušas to zemju nosaukumus, kur tās veidojušās. Tā arī latviešiem ir divas luteriskās baznīcas, kas nosaukumā nes piederību Latvijai. Tāda situācija izveidojusies, pateicoties sarežğîtajām vēsturiskajām norisēm Latvijā, kurām cauri ir gājusi arī 1922. gadā dibinātā Latvijas Evaṇgèeliski luteriskā baznīca, kuras satversmi pieņēma 1928. gadā, arī pēc ilgām diskusijām. Pēc Otrā pasaules kara liela daḷa Latvijas mācītāju un draudzes locekḷu atradās ārpus Latvijas un Latvijas Evaņgéliski luteriskā baznīca darbojās arī ārpus Latvijas. Vai luteriskā baznīca okupētajā Latvijā un baznīca ārpus Latvijas ir tās baznīcas turpinātājas, kas radās neatkarīgajā Latvijas valstī? Šis, protams, ir vēsturisks un arī juridisks jautājums, tomēr vispirmām kārtām tas ir teoloǵisks jautājums, jautājot, vai jebkura - pirmskara vai pēckara - baznīca atbilst nosaukumam "baznīca". Ja tā, tad šajā teologiskajā nozīmē var runāt par vienotu baznīcas identitāti. Jāatceras, ka Baznīcā no tās pirmsākumiem nekad nav pastāvējis tikai viens vienīgs teoloǵisks skatījums. Baznīca šajā ziṇā nav un nevar būt kopība, kas pārstāv tikai vienādus uzskatus. Arī iekšējās diskusijas, pat konflikti un tad izlīgumi vienmēr ir piederējuši pie baznīcas. Nav konfesionālā līmen̄̄ viena vispārēja formulējuma, kas ir baznīca. Katra konfesija savu identitāti formulē atškirīgi, tādēḷ svarīgi saredzēt, vai atsevišḳā baznīca atbilst noteiktajai konfesionālajai identitātei, šajā gadījumā luteriskajai identitātei. Tāpat piemērojams ir kritērijs par tās vēsts autentiskumu, proti, vai tā atbilst tam, kas no pašiem sākumiem ir saredzēts kā evanggèelijs, 
kā arī tās rīcība atbilst kristīgam etosam, proti, mīlestības bauslim. Tāpat nozīmīgi, vai atseviškso baznīcu citas baznīcas atzīst par baznīcu. Vērtējot pirmskara Latvijas luteriskās baznīcas pēc šiem kritērijiem, jāapstiprina, ka, ciktāl tas ir konstatējams dokumentāli, teoloǵiski šîs baznīcas ir baznīcas. Tātad pieder pie vienas identitātes. Juridiski un vēsturiski tas, protams, vēl ir risināms jautājums.

Dažādība vienas vai dažādu konfesiju robežās pašlaik arvien vairāk tiek debatēta ekumeniskajā dialogā. Arvien biežāk kristīgās baznīcas nonāk pie atziņas, ka tās baznīciskums l, loti būtiski tiek apdraudēts, ja dialogs starp dažādiem novirzieniem nav iespējams. Rakstā No konflikta uz kopību - ciktāl iespējama kopīga Baznīcas svinēšana? Dace Balode pievēršas luterāṇu un Romas katoḷu dialogam, kura rezultātā, gaidot 2017. gada reformācijas gadadienu, tika sagatavots dokuments $\mathrm{No}$ konflikta uz kopību. Tajā atkal vienu soli tālāk abas baznīcas ir satuvinājušās reformācijas izpratnē un tās mantojuma īstenošanā. Tomēr vēl joprojām jautājums par baznīcu definīciju, par to, ka baznīcas viena otru atzīst to baznīciskuma pilnībā, tātad kā līdzvērtīgu savai konfesijai, ir palicis ārpus š̄ dokumenta. Solis tālāk ir sperts pavisam nesen - Eiropas Protestantu baznīcu apvienība, kas apvieno luterānu, reformātu, metodistu un uniētās baznīcas no vairāk nekā trīsdesmit Eiropas valstīm, šogad 13.-19. septembrī kopsapulcē Bāzelē ir nolēmusi aicināt turpināt dialogu ar Romas Katoḷu baznīcu tieši par šo pašu galveno jautājumu baznīcu attiecībās.

Reformācija Latvijā ir ne tikai izmainījusi baznīcu ainavu teoloǵiskā ziṇā, bet arī ienesusi savas krāsas baznīcas arhitektūrā un mūzikā. Ralfs Kokins rakstā Ėdoles baznīcas iekārta: koktēlnieka Tobiasa Heinca 1647./1648. gadā darinātā altāra un kanceles teologiskie vēstījumi atspoguḷo šo kultūras mantojumu. Ēdoles baznīca, tāpat kā pils, ir leǵendām apvīta, savukārt baznīcas kokgriezumi ir liecība par tālaika teologiju, kas vizualizējusies gan baznīcā redzamajās koka figūrās, gan arī uzrakstos, kuri iegriezti altāra un kanceles ansamblī. Altāra retablā uzraksts Soli Deo gloria atgādina dažādos reformācijas sola (tikai) - tikai ticība, tikai žēlastība, tikai Raksti, tikai Kristus. Baznīcas iekārta kopumā atgādina par dzīves skaistumu, bet arī tās trauslumu un īsumu mūžības priekšā.

Rakstā Ieskats reformācijas gadsimta baznīcas mūzikā Rīgā Vilis Kolms aplūko reformācijas laika Livonijā rodamās liecības par pirmo luterisko mūziku Rīgā. Reformācija mainīja uzsvarus arī dievkalpojumos, un tas atstāja iespaidu uz mūziku, kas bija un ir loti nozīmīgs medijs dievkalpojumā. Dievkalpojumā lielāku nozīmi ieguva draudze kā dievkalpojuma nesēja, un arī mūzikā līdz ar to notika pietuvināšanās tautai. Pirmā liecība par luterisko mūziku no Rīgas gan nav tieši no dievkalpojuma, bet gan no dramatiska uzveduma Lìdzība par pazudušo dēlu, kura autors ir Burkhards Valdiss, luteriskajā ticībā pārgājis franciskāṇu mūks. Par dievkalpojumā dziedāto liecina pirmās luteriskās dziesmu grāmatas vācu valodā $(1530,1537)$, un, iespējams, latviešu draudzēs bija savas latviešu dziesmas, lai gan dziesmu grāmata izdota tikai 1587. gadā. Savu īpatnu mūziku sacerējis arī pirmais Livonijas reformators Andreass Knopkens, līdz ar to viņš pārstāv luteriskā korāḷa tradīijas, kas veidojās Baltijā. Pirmais luteriskās mūzikas profesionālis Rīgā bija Pauls Bucens, kura daiḷradē sastopami jau nopietnāki skaṇdarbi. Luteriskā teologija, atrodot savu izteiksmi mūzikā, ieguva pieeju dievlūdzējiem.

Reformācijas 500. gadadienu atzīmēja ļoti plaši dažādās zemēs, tomēr, protams, īpaša uzmanība tai bija veltīta Vācijā, kuras kultūra tik nesaraujami ir sasaistîta ar reformācijas lielo ieguldījumu. Emeritētais arhibīskaps Ernsts Elmārs Rozītis iepazīstina ar reformācijas atzīmēšanu Vācijā rakstā Luters un viña ietekme pēc 500 gadiem - aktuālais redzējums no Vācijas. Tā raksturojama ar atvērtību un dažādību: l̦oti bieži dažādās Vācijas pilsētās ar visdažādāko mediju palīdzību tika atgādināta reformācijas nozīme, bet arī tālāk interpretēts, ko tā ir devusi un dod mūsdienu sabiedrībai. Neapšaubāmi, arī apziņa par to, ka šis ir arī ekumeniski nozīmīgs notikums, pieder pie reformācijas turpmākās interpretācijas. Arī problemātiskais gan M. Lutera teolog̣ijā, gan arī reformācijas vēsturiskajās norisēs nebija aizmirsts un tiek kritiski izvērtēts. Viena no plašākajām baznīcas aktivitātēm, kurā piedalījās dažādu konfesiju pārstāvji no visas pasaules, bija reformācijas piecsimtgadei veltītās 
izstādes organizēšana Vitenbergā. Tajā sasta- veidu, kā sarunāties un piedzīvot Baznīcu. pās dažādas tradīcijas, dažādas valodas, da- Reformācija bija un ir iestāšanās par Baznīcu žādas pārliecības, dažādas baznīcas un atrada un par baznīcu.

\section{VĒRES}

Deschner, K. (1986-2014) Kriminalgeschichte des Christentums. Bd. 1-10.

Luz, U. (2014) Theologische Hermeneutik des Neuen Testaments. Neukirchen-Vluyn : Neukirchener Theologie.

Pannenberg, W. (1961) Offenbarung als Geschichte. Göttingen : Vandenhoeck und Ruprecht.

Weder, H. (1986) Neutestamentliche Hermeneutik. Zürich : Theologischer Verlag. 